\title{
南亚热带贫营养水库春季浮游植物群落 结构与动态
}

\section{李秋华 胡 韧 韩博平*}

(暨南大学水生生物研究所,广州 510632)

\begin{abstract}
摘 要 2005 年 1 6 月, 通过每两周一次的高频率采样, 对南亚热带贫营养水库一一梅溪水库的水文、营养盐和 浮游植物进行了调查, 并计算水体浮游植物生物量。主要结果如下:梅溪水库浮游植物具有物种少,生物量低, 以 飞燕角甲藻 (Ceratium hirundinella) 和多甲藻 (Peridinium sp.) 为优势藻的特征。12 次采样 24 个样品共检测到浮游植 物 42 种。浮游植物在早春 ( $1 \sim 3$ 月) 和晚春 ( $4 \sim 6$ 月) 有显著的差别, 其中每次采样浮游植物早春平均 13 种, 晚春 平均 21 种。浮游植物总的细胞丰度为 $31 \sim 273$ cells ml ${ }^{-1}$,总生物量为 $0.176 \sim 2.024 \mathrm{mg} \mathrm{L}^{-1}$ 之间。晚春浮游植物 平均生物量明显高于早春。低营养盐和弱酸性水体有利于能够垂直迁移获得营养的鞭毛藻类和其它藻类之间竞 争, 而使其成为整个春季优势类群。在晚春, 随着水温显著增加, 浮游植物丰度和生物量也明显增加, 但是降雨的 增加降低了水体的透明度, 大大减缓了由水温上升导致生物量增长的趋势。水温是梅溪水库浮游植物变化的主要 限制因子，但是降雨有明显的干扰作用。
\end{abstract}

关键词 浮游植物 动态 春季 水库

\section{SPRING DYNAMICS OF THE PHYTOPLANKTON COMMUNITY OF AN OLIGO- TROPHIC RESERVOIR IN THE SOUTHERN SUBTROPICS OF CHINA}

\author{
LI Qiu-Hua , HU Ren , and HAN Bo-Ping* \\ Institute of Hydrobiology , Ji' nan University , Guangzhou 510632 , China
}

\begin{abstract}
Aims The objective of this paper was to describe the phytoplankton community and dynamics of Meixi Reservoir , a small oligotrophic reservoir in the southern subtopics of China.

Methods Hydrological parameters, nutrition and phytoplankton were investigated at the center of the reservoir every two weeks in spring from January to June 2005. Nutrient concentrations were measured by BG38382002. Phytoplankton were identified, counted and measured with microscopes, and their biomass was calculated based on cell morphometrics .
\end{abstract}

Important findings The phytoplankton community was characterized by low species number, biomass and dominance by two dinoflagellate species, Ceratium hirundinella and Peridinium sp. In total, 42 taxa were identified from 24 samples. The community was distinctively different between early spring (January to March) and late spring (April to June). Only about 12 species were observed in each sampling in the early spring , but 21 species in the late spring. The total abundance of phytoplankton ranged from 31 to 273 cells $^{\mathrm{ml}^{-1}}$, and the total biomass of phytoplankton ranged from 0.176 to $2.024 \mathrm{mg} \mathrm{L}^{-1}$. The average biomass of phytoplankton was higher in late spring than in early spring. Dinoflagellates had an advantage in competition with other species and were able to move vertically to get nutrients from near the bottom of the reservoir. In late spring , phytoplankton abundance and biomass increased significantly with water temperature , but decreased with rainfall , apparently as water transparence declined due to disturbance from precipitation. Therefore , water temperature was the main factor restricting the phytoplankton community, but was disturbed by rainfall. This study provided base data for phytoplankton communities in oligotrophic water bodies and was helpful to understand possible changes with cultural eutrophication.

Key words phytoplankton, dynamics, spring, reservoir 
在自然水体中, 浮游植物群落的组成与结构取 决于水体的物理、化学和生物环境。当浮游动物和 鱼类的植食压力较低时, 光强、水温和营养盐是决定 水体浮游植物群落特征的主要因子(González, 2000； Horn , 2003 ; Naselli-Flores, 2000)。在一些水体, 水 动力学条件也可成为影响浮游植物的主要因子, 这 取决于水体的性质(卢敬让等，1994;Beyruth，2000)。 在高纬度地区水体存在典型水温季节变化, 水柱的 垂直混合导致水体营养盐的增加,在春秋两季出现 以硅藻为优势类群的浮游植物群落类型 (Serra et $a l$. ,2002)。在寡营养水体中, 这种由水温为主导因 子调节的浮游植物群落季节变化尤其明显 (Salmaso， 2000)。相比之下, 对热带亚热带地区的浮游植物组 成与季节变化的研究要少得多 (Kotou et al. , 1998 ; Piet \& Vijverberg，1999)。由于这些地区的水温常年 较高, 季节变化不如高纬度明显, 受水温的影响相对 小, 浮游植物群落组成多样化与动态变化较为复杂 (Negro et al. , 2000)。在热带亚热带低纬度地区 现 有的水体浮游植物研究多数以富营养化管理为出发 点, 对寡营养水体的报道极少。在我国华南低纬度 地区, 土壤以红壤为主, 呈酸性, 水体中本底的营养 水平较低。随着人类活动的范围和强度增加, 寡营 养水体锐减(韩博平等，2003)。本文以珠海一座小 型寡营养水库为对象, 对该水库的春季浮游植物群 落的组成进行了系统的采样, 分析了其组成与结构 的变化。本研究不仅可提供该类水体浮游植物组成 的基本数据, 同时也可为认识在人类活动影响下这 类水体在富营养化过程中浮游植物变化的特 征。

\section{1 材料和方法}

\section{1 水库概况}

梅溪水库是一座小型城市供水水库, 位于广东 省珠海市北部 $\left(22^{\circ} 34^{\prime} 12.0^{\prime \prime} \mathrm{N}, 114^{\circ} 09^{\prime} 03.3^{\prime \prime} \mathrm{E}\right)$, 在北 回归线以南, 水体温度常年较高。梅溪水库集雨面 积为 $1.74 \mathrm{~km}^{2}$,多年平均降雨量为 $1865 \mathrm{~mm}$, 水库总 库容为 $2.14 \times 10^{6} \mathrm{~m}^{3}$, 正常 库容为 $1.73 \times 10^{6} \mathrm{~m}^{3}$, 正 常水位为 $21.20 \mathrm{~m}$, 水库平均深 $6 \mathrm{~m}$ 左右。没有河流 输入, 降雨是梅溪水库入库水流主要来源。由于受 土壤和降雨的影响, 梅溪水库水体 $\mathrm{pH}$ 值表现出弱 酸性。

\section{2 采样与实验方法}

2005 年 $1 \sim 6$ 月, 在水库中央采样, 每两周一次， 用 YSI 水质仪现场测定水温、溶解氧 (Dissolved oxy-
gen，DO）;用塞氏盘测定透明度（Secchi disk depth， SD) ; 用 pHS-3C 酸碱度计测定水体的 $\mathrm{pH}$ 值。降雨 量采用全自动监测仪测定。水化指标的采样总磷 (Total phosphorus，TP)、总氮 (Total nitrogen，TN) 实验 用水用 $250 \mathrm{ml}$ 的白色玻璃瓶盛装; 硝酸盐氮 $\left(\mathrm{NO}_{3}\right.$ $\mathrm{N})$ 、亚硝酸盐氮 $\left(\mathrm{NO}_{2}-\mathrm{N}\right)$ 、氨态氮 $\left(\mathrm{NH}_{4}-\mathrm{N}\right)$ 、正磷酸盐 磷 $\left(\mathrm{PO}_{4}-\mathrm{P}\right)$ 实验用水经过抽滤器用 $0.45 \mu \mathrm{m}$ 的纤维 虑膜抽滤后盛装在棕色的 $500 \mathrm{ml}$ 的玻璃瓶中, 带回 实验室后在 $24 \mathrm{~h}$ 内立即处理和测定。水化指标均 按照国家水质标准方法 GB3838-2002 进行实验。叶 绿素 $\mathrm{a}$ 采用经过 $0.45 \mu \mathrm{m}$ 的纤维滤膜抽滤 $500 \mathrm{ml}$,反 复冻融-浸提, 运用改进的丙酮萃取方法进行实验 (林少君等,2005)。浮游植物定量样品在表层 $0.5 \mathrm{~m}$ 处采取 $2 \mathrm{~L}$ 水样, 用 $5 \%$ 福尔马林固定, 在实验室浓 缩沉淀, 浮游植物定性样品用 25 号浮游生物网 (64 $\mu \mathrm{m})$ ，在不同方向进行拖网，同样用 $5 \%$ 福尔马林固 定(章宗涉和黄祥飞,1991)。浮游植物定性、定量样 品均在显微镜下进行鉴定和计数。藻类生物体积根 据各藻类相近几何形状的体积公式计算 (金相灿和 屠清瑛, 1990; 孙军等, 1999）,假定浮游植物藻类的 密度为 $1.1 \mathrm{~g} \mathrm{~cm}^{-3}$, 计算水体浮游植物生物量。

\section{2 结果与分析}

\section{1 梅溪水库理化特点}

梅溪水库地处热带地区北缘, 水体的温度常年 都较高。2005 年春季采样期间, 每次采样的水温均 在 $14{ }^{\circ} \mathrm{C}$ 以上。最低温度出现在 3 月 1 日的调查中， 最高出现在 5 月中旬, 达 $30{ }^{\circ} \mathrm{C}$ 。早春 (1 3 月) ,梅 溪水库水温平均为 $17{ }^{\circ} \mathrm{C}$, 水温的变化较小, 而晚春 (4 6 月) 的水温平均温度为 $27{ }^{\circ} \mathrm{C}$, 要高出 $1 \sim 3$ 月 平均温度 $10{ }^{\circ} \mathrm{C} 。 1 \sim 3$ 月梅溪水库降雨量较少, 3 个 月仅降雨 $66.8 \mathrm{~mm}$ 。 3 月以后, 进入丰水期。4 6 月降雨量明显增加，总降雨量达 $1031.2 \mathrm{~mm}$, 远超过 $1 \sim 3$ 月降雨量 (图 1A)。梅溪水库的 $\mathrm{pH}$ 值偏低, 呈 弱酸性, 表层 $\mathrm{pH}$ 值平均为 7.0 , 而各层的 $\mathrm{pH}$ 值平均 为 6.26。4 月表层水的 $\mathrm{pH}$ 最低, 为 5.56 。梅溪水库 水体 $\mathrm{pH}$ 值表现出弱酸性, 主要受土壤性质和降雨 的影响。在早春水体透明度较高, 而在晚春透明度 有所下降, 这主要是与降雨有关。梅溪水库没有河 流相连，入库水流主要来源于降雨，当降雨增加时， 水库沿岸裸露的坡地形成一定的水土侵蚀。从 3 月 开始、随着降雨增加, 沿岸水体出现浑浊并向库中扩 展, 导致水体的透明度降低。水体的透明度与降雨 量存在明显的负相关 $(n=12, p=0.005, p<0.01$, 


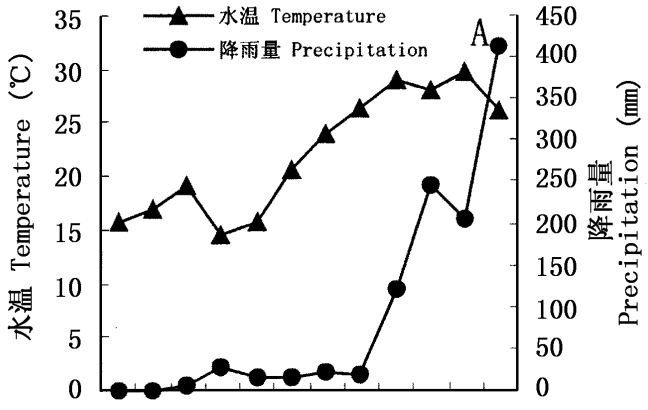

a $b$ c d e

日期 Date

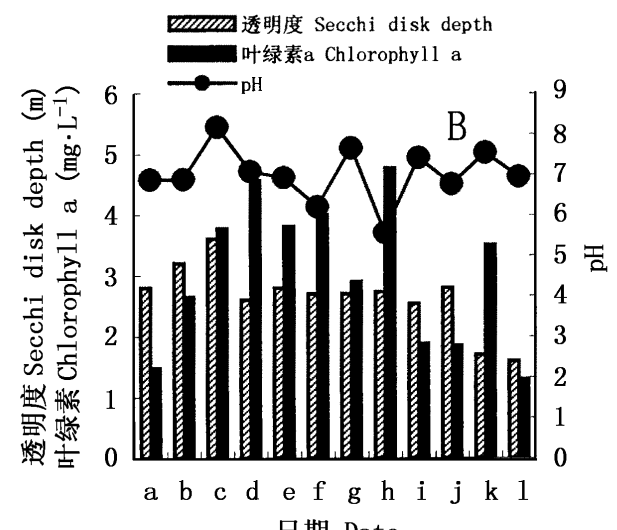

图 1 梅溪水库水温和降雨量 $(\mathrm{A}) 、 \mathrm{pH}$ 、透明度和 叶绿素 $\mathrm{a}(\mathrm{B})$ 春季动态变化

Fig. 1 The dynamics of temperature and precipitation (A) , $\mathrm{pH}$, Secchi disk depth and chlorophyll a (B) in spring in Meixi Reservoir $\mathrm{a}: 1$ 月 11 日 11-Jan. $\mathrm{b}: 1$ 月 28 日 28-Jan。 $\mathrm{c}: 2$ 月 17 日 17Feb. d 3 月 1 日 1-Mar. e : 3 月 16 日 16-Mar. f : 3 月 31 日 31Mar. g A 月 15 日 15-Apr. h 4 月 30 日 30-Apr. i :5月 16 日 16May j 6月1日 1-June k 6月 15 日 15-June 1:6月30日 30-June

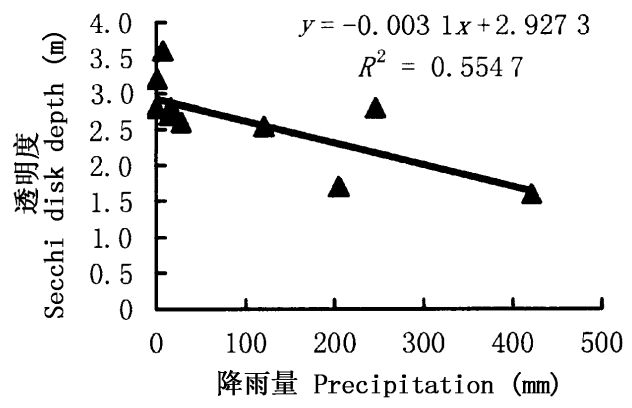

图 2 梅溪水库降雨量与透明度相关关系

Fig. 2 The correlation between precipitation and secchi disk depth in Meixi Reservoir

$\left.R^{2}=0.5547, Y_{\text {透明度 }}=-0.0031 X_{\text {降雨量 }}+2.9273\right)$ (图 2)。梅溪水库的叶绿素浓度较低, 最低为 1.3 $\mu \mathrm{g} \mathrm{L}^{-1}$ 最高时也只有 $4.7 \mu \mathrm{g} \mathrm{L}^{-1}$ 。1 2 月叶绿素 的含量低,而 $2 \sim 4$ 月较高 $5 \sim 6$ 月又有所下降。

从营养盐浓度看 (表 1), 梅溪水库营养盐浓度
比较低,为典型的贫营养型水体。总氮的平均浓度 约为 $0.564 \mathrm{mg} \mathrm{L} \mathrm{L}^{-1}$,总磷的平均浓度在 $0.020 \mathrm{mg}$ $\mathrm{L}^{-1}$ 营养盐浓度动态变化不明显, 早春的总氮和硝 态氮略高于晚春。平均总氮与总磷的原子比为 $62.4: 1$, 浮游植物的生长受磷限制。

表 1 梅溪水库营养盐的平均值

Table 1 The concentrations of nutrients in Meixi Reservoir

\begin{tabular}{lccc}
\hline & $\begin{array}{c}1 \sim 3 \text { 月 } \\
\text { January to } \\
\text { March }\end{array}$ & $\begin{array}{c}4 \sim 6 \text { 月 } \\
\text { April to } \\
\text { June }\end{array}$ & $\begin{array}{c}1 \sim 6 \text { 月 } \\
\text { January to } \\
\text { June }\end{array}$ \\
\hline $\mathrm{NO}_{2}-\mathrm{N}\left(\mathrm{mg} \mathrm{L}^{-1}\right)$ & 0.003 & 0.001 & 0.002 \\
$\mathrm{NO}_{3}-\mathrm{N}\left(\mathrm{mg} \mathrm{L}^{-1}\right)$ & 0.291 & 0.261 & 0.280 \\
$\mathrm{NH}_{4}-\mathrm{N}\left(\mathrm{mg} \mathrm{L}^{-1}\right)$ & 0.026 & 0.026 & 0.026 \\
$\mathrm{TN}\left(\mathrm{mg} \mathrm{L}^{-1}\right)$ & 0.610 & 0.520 & 0.564 \\
$\mathrm{PO} \mathrm{P}_{4}\left(\mathrm{mg} \mathrm{L}^{-1}\right)$ & 0.004 & 0.007 & 0.006 \\
$\mathrm{TP}\left(\mathrm{mg} \mathrm{L}^{-1}\right)$ & 0.020 & 0.019 & 0.020 \\
\hline
\end{tabular}

$\mathrm{TN}$ : 总氮 Total nitrogen TP : 总磷 Total phosphorus

\section{2 浮游植物群落结构与组成}

在调查期间 梅溪水库春季 12 次采样, 24 个样 品共检测到浮游植物 42 种,分属 7 门,物种分布见 表 2 ,物种的统计见图 3。在所检测到的浮游植物 中 梅溪水库浮游植物主要是由绿藻门和硅藻门的 藻类组成。绿藻门的藻类有 21 种, 占 $51.2 \%$, 硅藻 门的藻类有 11 种, 占 $25.6 \%$ 。蓝藻门 4 种, 甲藻门、 金藻门各 2 种, 裸藻门、隐藻门各 1 种。早春 $(1 \sim 3$ 月)浮游植物物种较少, 每次采样约有 13 种。在 3 月中旬的水样中, 检测到浮游植物物种最少, 为 8 种。到了晚春 $A \sim 6$ 月浮游植物种数平均达 21 种， 浮游植物物种有了明显的增加。增加的物种主要来 自蓝藻、硅藻和绿藻 ;其中, 蓝藻增加了 4 种, 绿藻增 加了 6 种, 硅藻增加了 5 种;甲藻、金藻和裸藻的物 种基本没有变化。在 4 月, 浮游植物的种数增加最 为明显, 出现了蓝藻门的具缘微囊藻 (Microcystis marginata)、小形色球藻 (Chroococcus minutus)、假鱼 腥藻 ( Pseudanabaena sp.) 和拟柱狍藻 (Cylindrospermopsis sp. ) 绿藻门的长绿梭藻 (Chlorogonium elongatum)、厚变浮游角星鼓藻 (Staurastrum natator)、二形 椓藻 (Scenedesmus dimorphus) 和月牙藻 (Selenastrum bibraianum) 硅藻门的窗格平板藻 ( Tabellaria fenestri$a t a$ ) 和根管藻 (Rhizosolenia sp.) 等。甲藻为梅溪水 库春季的主要优势藻, 其中飞燕角甲藻在每次的水 样中均为优势藻, 而多甲藻从 3 月开始和飞燕角甲 藻一起成为水库的优势藻。硅藻门的肘状针杆藻 (Synedra ulna) 和梅尼小环藻 (Cyclotella meneghiniana)、裸藻门的棘刺囊裸藻 (Trachelomonas hispida)每 
表 2 梅溪水库春季浮游植物组成

Table 2 Species composition of phytoplankton communities in spring in Meixi Reservoir

$\begin{array}{llllllllll}\text { 物种 Taxon } & \text { a } & \text { b } & \text { c } & \text { d } & \text { e } & \text { f } & \text { g } & \text { h }\end{array}$

\section{绿藻门 Chlorophyta}

双对栅藻 Scenedesmus bijugatus

单角盘星藻 Pediastrum simplex

单角盘星藻具孔变种 Pediastrum simplex var. duodenarium

凹顶鼓藻 Euastrum spp.

钝角角星鼓藻 Staurastrum retusum

厚变浮游角星鼓藻 Staurastrum natator

微小四角藻 Tetraëdron minimum

小球藻 Chlorella vulgaris

韦斯藻 Westella botryoides

蹄形藻 Kirchneriella lunaris

水绵 Spirogyra sp.

布朗葡萄藻 Botryococcus braunii

二角盘星藻 Pediastrum duplex

微芒藻 Micractinium pusillum

放射多芒藻 Golenkinia radiata

二形栅藻 Scenedesmus dimorphus

空星藻 Coelastrum spaericum

长绿梭藻 Chlorogonium elongatum

异刺四星藻 Tetrastrum heterocanthum

顶接鼓藻 Spondylosium moniliforme

月芽藻 Selenastrum bibraianum

硅藻门 Bacillariophyta

梅尼小环藻 Cyclotella meneghiniana

肘状针杆藻 Synedra ulna

曲壳藻 Achnanthes sp.

颗粒直链藻 Melosira granulata

异极藻 Gamphonema sp.

舟形藻 Navicula spp.

羽纹藻 Pinnularia spp.

桥弯藻 Cymbella laevis

窗格平板藻 Tabellaria fenestriata

模糊直链藻 Melosira ambigua

根管藻 Rhizosolenia sp.

甲藻门 Pyrrophyta

飞燕角甲藻 Ceratium hirundinella

多甲藻 Peridinium sp.

金藻 Chrysophyta

分歧雉囊藻 Dinobryon divergens

具尾鱼鳞藻 Mallomonas caudata

裸藻门 Euglenophyta

棘刺囊裸藻 Trachelomonas hispida

隐藻门 Cryptophyta

隐藻 Crytomonas sp.

蓝藻门 Cyanophyta

具缘微囊藻 Microcystis marginata

小形色球藻 Chroococcus minutus

假鱼腥藻 Pseudanabaena sp.

拟拄狍藻 Cylindrospermopsis sp.

$\begin{array}{llllllllllllllllll}++ & +++ & +++ & +++ & +++ & +++ & +++ & +++ & +++ & +++ & +++ & +++\end{array}$

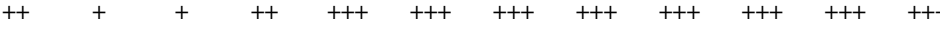

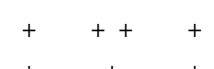

$+\quad+\quad+$ 


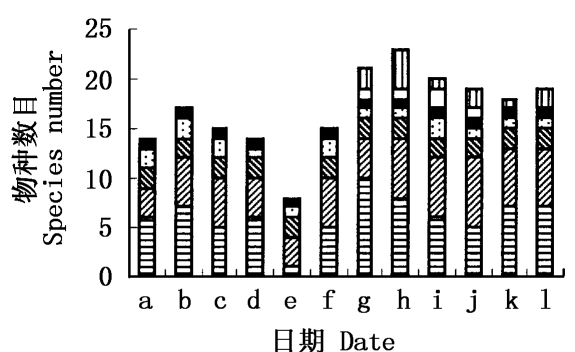

曰绿藻 Chlorophyceae 甲藻 Pyrrophyceae 1裸藻 Euglenophyceae 四蓝藻 Cyanobacteria

图 3 梅溪水库春季浮游植物组成

Fig.3 Phytoplankton composition in Meixi Reservoir in spring 2005 a 1 : 见图 1 See Fig. 1

次采样中都能检测到，绿藻门的小球藻 (Chlorella vulgaris) 和布朗葡萄藻 (Botryococcus braunii)、硅藻门 的曲壳藻 (Achnanthes sp.) 和舟形藻 (Navicula spp.)、 金藻门的分歧雉囊藻 (Dinobryon divergens) 出现的频 率也较高, 仅 $2 \sim 3$ 次未检测到。

\section{3 浮游植物细胞丰度与组成动态变化}

梅溪水库浮游植物的细胞丰度在 31 273 cells $\mathrm{ml}^{-1}$ 之间变化 (图 4A)。在 1 2 月细胞丰度较低, 从 3 月开始明显增加, 在 3 月中旬出现浮游植物细 胞丰度的一个明显的峰值。早春 ( $1 \sim 3$ 月) ,梅溪水 库浮游植物的细胞丰度变化较大, 呈增加的趋势, 但 1 月底和 3 月初时出现了两个低值。晚春 (4 6 月) 的浮游植物细胞丰度明显高于早春, 波动相对较少, 在 6 月中旬出现第二个峰值。从浮游植物物种组成 来看 梅溪水库的浮游植物主要由甲藻、硅藻、绿藻 组成, 还有少数的裸藻和蓝藻。在 $1 \sim 2$ 月, 甲藻和 硅藻的组成比例较高 3 月中旬, 由于硅藻门中的曲 壳藻、梅尼小环藻、肘状针杆藻和裸藻门中的棘刺囊 裸藻增加较快, 导致甲藻的比例有所下降, 甲藻的细 胞丰度百分数仅为 $17 \%$ 。甲藻门的飞燕角甲藻和 多甲藻一直是梅溪水库的优势种，细胞丰度在 $13 \sim$ 148 cells $\mathrm{ml}^{-1}$ 之间, 这两种藻类占了整个藻类细胞 丰度的 17\% 57\% (图 4B)。在 1 月，飞燕角甲藻细 胞丰度最多, 为 31.5 cells $\mathrm{ml}^{-1}$,之后变化较小。多 甲藻的变化较大, 在 1 月细胞丰度较低, 在 3 月末细 胞丰度达到最高值; 进入晚春后, 其细胞丰度有变 化, 但仍维持较高细胞丰度, 是水库浮游植物的主要 优势种。4 6 月 梅溪水库出现了绿藻门的许多物 种 其中以小球藻、韦斯藻 (Westella botryoides) 细胞 丰度增加最多。这样在 4 月以后 梅溪水库以甲藻、 绿藻、硅藻为主出现。从 4 月开始, 水样中检测到了
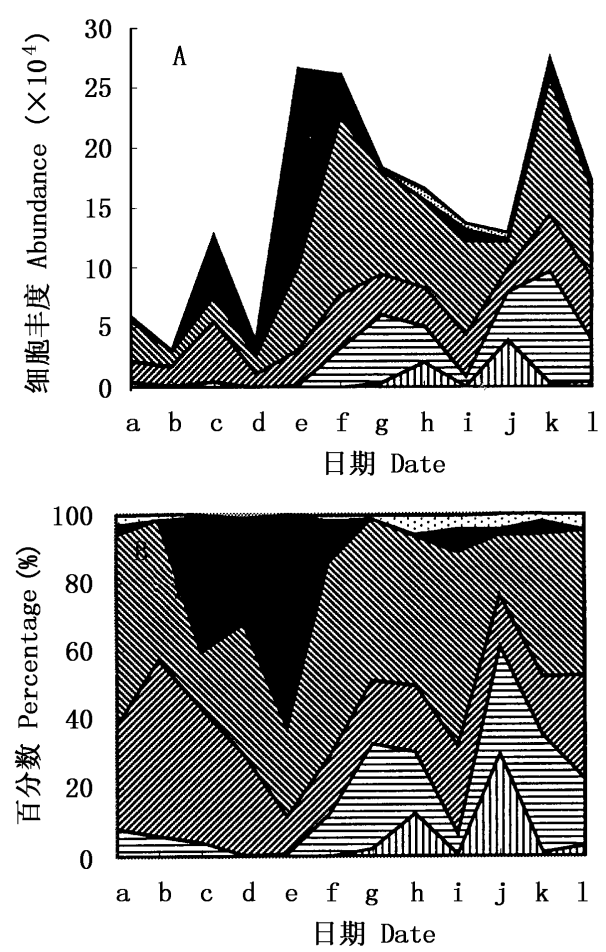

四蓝藻 Cyanobacteria 日绿藻 Chlorophyceae

硅藻 Bacillariophyceae $\mathbf{N}$ 甲藻 Pyrrophyceae

口裸藻 Euglenophyceae 口金藻 Chrysophyceae

图 4 梅溪水库春季浮游植物细胞丰度动态 (A)细胞丰度 ,(B)组成\%

Fig.4 The dynamics of cells abundance (cells $\left.\mathrm{ml}^{-1}\right)$ (A) and composition (\%) (B) in spring in Meixi Reservoir $\mathrm{a} \sim 1$ : 见图 1 See Fig. 1

蓝藻, 主要为假鱼腥藻和小形色球藻, 但所占的比例 较低, 没有成为优势种。

\section{4 浮游植物生物量动态变化}

梅溪水库浮游植物的生物量在 $0.176 \sim 2.024$ $\mathrm{mg} \mathrm{L} \mathrm{L}^{-1}$ 之间变化(图 5A), 2 月末梅溪水库浮游植物 的生物量最低, 但是在 3 月很快达到最高值。浮游 植物的生物量主要由甲藻门飞燕角甲藻和多甲藻的 生物量组成, 其生物量占整个浮游植物生物量的 $76.5 \% \sim 95.5 \%$, 其它藻类对浮游植物生物量的贡 献较小。可见, 甲藻对梅溪水库浮游植物生物量贡 献大, 而且相对较稳定。在 3 月末, 甲藻生物量处于 最大值, 达到 $1.936 \mathrm{mg} \mathrm{L} \mathrm{L}^{-1}$ 。1 3 月飞燕角甲藻的 生物量占绝对优势; 3 月末, 由于多甲藻的迅速增 加 和飞燕角甲藻一起成为梅溪水库的主要优势种 (图 5B)。梅溪水库甲藻生物量和浮游植物生物量 总量有较强的相关性 $\left(n=12, R^{2}=0.996, p<\right.$ $0.01)$,也说明梅溪水库甲藻生物量在水库浮游植物 生物量中占绝对优势。硅藻是梅溪水库次优势类 
群, 在 2 月, 梅尼小环藻、时状针杆藻和曲壳藻有明 显增加，占浮游植物生物量的 $22.5 \%$ 。裸藻在整个 春季均有出现, 其生物量仅在 3 月中旬相对较高，约 占 $15 \%$ 。绿藻的生物量在整个春季都不高, 但是在 4 月, 由于二形栅藻、厚变浮游角星鼓藻、小球藻、韦 斯藻的细胞丰度增加，绿藻的生物量约占总生物量 的 $11 \%$ 。4 月开始, 水样中出现了金藻和蓝藻, 但是 金藻和蓝藻生物量极低。
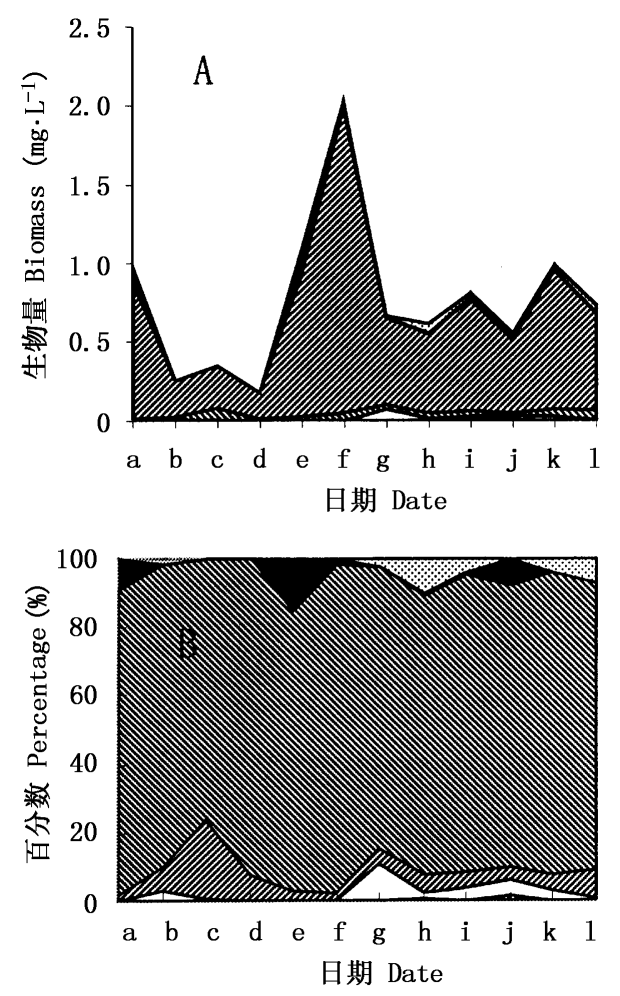

四蓝藻 Cyanobacteria 日绿藻 Chlorophyceae

硅藻 Bacillariophyceae $\mathbf{Q}$ 甲藻 Pyrrophyceae

裸藻 Euglenophyceae

口金藻 Chrysophyceae

图 5 梅溪水库春季浮游植物生物量动态 (A)生物量, (B) 组成\%

Fig.5 The dynamics of biomass (A) and the biomass composition (\%) (B) in spring in Meixi Reservoir a 1 : 见图 1 See Fig. 1

\section{3 讨 论}

梅溪水库是一个位于亚热带北缘的水库, 浮游 植物群落的结构和组成在春季有着明显变化规律。 在早春 (1 3 月) 和晚春 ( $4 \sim 6$ 月), 浮游植物的物种 丰度和平均生物量有了明显的增加。物种的增加主 要为一些喜高温的绿藻和蓝藻大量出现。浮游植物 生物量的变化主要优势种的生物量增加。甲藻中的 飞燕角甲藻一直是梅溪水库的优势种, 而多甲藻从 3 月后也成为一个主要的优势种。这两种甲藻在水
库浮游植物细胞丰度和生物量中均占绝对优势, 硅 藻只早春的初期, 在生物量上占有较高的比例。与 温带水体相比 梅溪水库春季浮游植物群落的动态 反映了热带水体自身的特点。

梅溪水库是一个典型的贫营养水体，不仅营养 盐水平低, 而且水体呈弱酸性, 有利于甲藻类的浮游 植物获得竞争优势。甲藻利用营养的方式较为复 杂,一些分类学家将其归为原生动物。甲藻能够进 行垂直迁移, 当水表层营养盐浓度较低时, 甲藻可通 过迁移利用下层的营养盐, 并且营养方式复杂, 从而 在贫营养水体中保持较好的竞争能力 (Zohary, 2004 ; Rengfors \& Legrand，2001)。在晚春期间，水体 表层的营养盐有所下降, 但甲藻的优势度提高, 也说 明了梅溪水库中飞燕角甲藻和多甲藻对贫营养条件 的适应能力较强。其中多甲藻比飞燕角甲藻的能力 更强, 在晚春水体分层后, 多甲藻的生物量得到了显 著增加。一方面可能是由于水温增加, 细胞生长加 快, 但其在贫营养水体中获得营养盐的能力可能更 为重要。其次 梅溪水库呈弱酸性, 不利于多数藻类 的生长, 也间接地有助于甲藻获得优势。在酸性水 体, $\mathrm{H}^{+}$的浓度增加, 水体游离的碳酸 $\mathrm{H}_{2} \mathrm{CO}_{3}$ (或 $\mathrm{CO}_{2}$ ) 增多, $\mathrm{HCO}_{3}{ }^{-}$的消耗减少, 浮游植物的代谢降低, 藻 类生长受到抑制，导致了浮游植物的藻类生物量较 低(Figueredo \& Giani ,2001; An \& Jones , 2000)。pH 值降低,一方面能够明显减少水库中心硅藻和蓝藻、 裸藻, 另一方面能够有利于形成单一藻类 (Korneva， 1996)。这样使得甲藻中的飞燕角甲藻和多甲藻这 类耐弱酸性的物种成为优势种。

早春和晚春的浮游植物物种和生物量的变化主 要与水温有关, 并受降雨的影响。早春的水温平均 为 $17{ }^{\circ} \mathrm{C}$, 而晚春的平均温度达 $27{ }^{\circ} \mathrm{C}$ 。水温的变化 在 3 月末最为明显,生物量有了明显的增加。在 4 月初, 浮游植物物种有了显著的增加。光强和水温 的增加促进了浮游植物的光合生产, 导致晚春浮游 植物生物量显著地高于早春。由于从 3 月初开始降 雨, 降雨有了明显增加, 导致水体中营养盐水平略 有下降, 同时透明度下降, 减缓了由于水温导致的生 物量增加趋势, 从而出现了 $4 \sim 5$ 月的生物量较 3 月 略低的现象。在很多水体, 水文条件对浮游植物群 落结构与组成的影响明显 (Horn , 2003)。但由于梅 溪水库缺乏入库河流, 降雨不能明显地增加营养盐 的输入, 而导致了透明度的下降, 降雨对浮游植物的 影响不同于其它水库。在流溪河等主要以入库河流 输入营养盐的水体, 降雨通常会明显地导致浮游植 
物生物量的增加(林秋奇等, 2003)。

流溪河水库和新丰江水库也是位于广东省境内 的贫营养型水库, 由于受流域特征的影响, 春季浮游 植物组成的变化与梅溪水库不同。流溪河水库水体 滞留时间相对短 (120d 左右), 水位波动较大, 春季 浮游植物主要是由适应这种环境生长的硅藻为主 (林秋奇,2003)。新丰江水库是广东省最大的水库， 全年硅藻占优势, 春季更为明显, 主要是颗粒直链藻 (Melosira granulata) 和梅尼小环藻, 甲藻在春季也有 较高的细胞丰度 (钟秀英等, 2003)。梅溪水库和这 两座水库相比较, 水库水体滞留时间长, 水位波动较 小, 水体稳定, 有利于具有鞭毛的甲藻成为优势种。

\section{参 考 文 献}

An KG, Jones JR (2000). Factors regulating bluegreen dominance in a reservoir directly. Hydrobiologia, 432, $37-48$.

Beyruth Z (2000) . Periodic disturbances, trophic gradient and phytoplankton characteristics related to cyanobacterial growth in Guarapiranga Reservoir, São Paulo State, Brazil. Hydrobiologia, $424,51-65$.

Figueredo CC, Giani A(2001). Seasonal variation in the diversity and species richness of phytoplankton in a tropical eutrophic reservoir. Hydrobiologia, 445, $165-174$.

González EJ (2000). Nutrient enrichment and zooplankton effects on the phytoplankton community in microcosms from EI Andiano reservoir(Venezuela). Hydrobiologia, 434, 81-96.

Han BP (韩博平), Li T (李铁), Lin XD (林旭钿) (2003). Reservoir Trophic States and the Study of Strategies of Prevention in Guangdong Province (广东省大中型水库富营养化现状与 防治对策研究). Science Press, Beijing. (in Chinese)

Horn H (2003). The relative importance of climate and nutrients in controlling phytoplankton growth in Saidenbach Reservoir. Hydrobiologia, 504, 159 - 166.

Jin XC (金相灿)，Tu QY(屠清瑛)（1990）. The Standard Methods in Lake Eutrophication Investigation (湖泊富营养化调查规 范). China Environmental Science Press, Beijing. (in Chinese)

Kotou K, Krientz L, Muthuri FM (1998). Temporal changes in phytoplankton structure and composition at the Turkwel Gorge reservoir, Kenya. Hydrobiologia, 368, $41-59$.

Korneva LG (1996). Impact of acidification on structural organization of phytoplankton community in the forest lakes of the northwestern Russion. Water Science Technology, 33, $291-296$.

Lin QQ (林秋奇), Hu R (胡韧), Han BP (韩博平) (2003). Effect of hydrodynamics on nutrient and phytoplankton distribution in Liuxihe Reservoir. Acta Ecologica Sinica (生态学报), 23, 2278 - 2284. (in Chinese with English abstract)
Lin SJ (林少君), He LJ (贺立静), Huang PS (黄沛生), Han BP (韩博平) (2005). Comparison and improvement on the extraction method for chlorophyll a in phytoplankton. Ecologic Science (生态科学), 24, 9-11. (in Chinese with English abstract)

Lu JR (卢敬让), Li DS (李德尚), Zhou CS (周春生) (1994). Studies on plankton of the large- and middle-sized reservoir in Shandong Province. III. Relationships between phytoplankton and environmental factors. Journal of Ocean University of Qingdao (青岛海洋大学学报), 24,505-510. (in Chinese with English abstract)

Naselli-Flores L (2000). Phytoplankton assemblages in twenty-one Sicilian reservoirs: relationships between species composition and environmental factors. Hydrobiologia, 424, 1-11.

Negro AI, Hoyos CD, Vega J (2000). Phytoplankton structure and dynamics in Lake Sanabria and Valparaiso reservoir(NW Spain). Hydrobiologia, 424, $25-37$.

Piet GJ, Vijverberg J (1999). Environmental perturbation and the structure and functioning of tropical aquatic ecosystem. Journal of Aquatic Ecosystem Stress and Recovery, 6, 265-279.

Rengfors K, Legrand C (2001). Toxicity in Peridinium aciculiferum - an adaptive strategy to outcompete other winter phytoplankton? Limnology and Oceanography, 46, 1990 - 1997.

Salmaso N (2000) . Factors affecting the seasonality and distribution of cyanobacteria and chlorophytes: a case study from the large lakes south of the Alps, with special reference to Lake Garda. Hydrobiologia, 438, 43-63.

Serra T, Colomen J, Baserba C, Solen M, Casamitjana X (2002). Quantified distribution of diatoms during the stratified period of Boadella reservoir. Hydrobiologia, 589, 235-244.

Sun J (孙军), Liu DY (刘东艳), Qian SB (钱树本) (1999). Study on phytoplankton biomass. I . Phytoplankton measurement biomass from cell volume or plasma volume. Acta Oceanologica Sinica (海洋学报), 21, 75-85. (in Chinese with English abstract)

Zhong XY (钟秀英), Yang HW (杨浩文), Chen LF (陈丽芬), Han BP (韩博平) (2003). The eutrophication of Xinfengiiang Reservoir. In: Han BP (韩博平), Li T (李铁), Lin XD (林 旭钿) eds. Reservoir Trophic States and the Study of Strategies of Prevention in Guangdong Province (广东省大中型水库富营养 化现状与防治对策研究). Science Press, Beijing. (in Chinese)

Zohary T (2004) . Changes to the phytoplankton assemblage of Lake Kinneret after decades of a predictable, repetitive pattern. Freshwater Biology, 49, 1355 - 1371 .

Zhang ZS (章宗涉), Huang XF (黄祥飞) (1991). Study Method on Freshwater Plankton (淡水浮游生物研究方法). Science Press, Beijing. (in Chinese) 